\title{
Effect of Different Levels of Pruning on Quality of Custard Apple (Annona squmosa L.)
}

\author{
S. R. Kadam, R. M. Dheware and P. S. Urade*
}

Dept. of Horticulture, College of Agriculture, Vasantrao Naik Marathwada Krishi Vidyapeeth, Parbhani, Latur, M. S. (431 402), India

\section{Corresponding Author}

P. S. Urade

e-mail: poojaurade1494@gmail.com

\author{
Article History \\ Article ID: AR1865c \\ Received in $15^{\text {th }}$ March, 2018 \\ Received in revised form $25^{\text {th }}$ September, 2018 \\ Accepted in final form $01^{\text {st }}$ October, 2018
}

\begin{abstract}
Pruning and defoliation are essential operations for inducing off-season flowering and fruiting to yield better quality and quantity of fruits in custard apple. A study was undertaken to investigate the effect of different levels of pruning on growth and quality of custard apple (Annona squamosa L.), cultivar Dharur- 6 of eight years old plants spaced at $4 \times 4 \mathrm{~m}^{2}$. studied at custard apple, Research Station, Ambajogai, district Beed during the year 2016-2017. The data has been statistically analyzed by using Randomized Block design. In this experiment, six pruning treatments $(5 \mathrm{~cm}, 10 \mathrm{~cm}, 15 \mathrm{~cm}, 20 \mathrm{~cm}, 25 \mathrm{~cm}$ and control) were taken after harvesting of previous year fruits. Shoot emergence was found earlier, in pruned trees as compared to unpruned trees. The statistical analysis revealed that, the treatment Pruning at $20 \mathrm{~cm}$ shows maximum weight of fruit ( $263 \mathrm{~g})$, weight of pulp (110.7) and weight of peel (131.23 g) ware recorded. Maximum total soluble solid $(23.80 \%)$ was recorded in the treatment pruning at $20 \mathrm{~cm}$. Maximum reducing sugar $(18.50 \%)$ was recorded in treatment pruning at 15 $\mathrm{cm}$. Significantly maximum non-reducing sugar $1.88 \%$ was observed in treatment Pruning at $15 \mathrm{~cm}$. Significantly maximum total sugar $20.38 \%$ was recorded in the treatment Pruning at $15 \mathrm{~cm}$. Hence, it is therefore suggested that treatment pruning at $20 \mathrm{~cm}$ can be used to maintain growth and quality of custard apple.
\end{abstract}

Keywords: Custard apple (Annona squamosa L.), pruning levels, treatments, quality

\section{Introduction}

Pruning is one of the horticultural practices fallowed in deciduous \& temperate fruit crops like apple, pear, peach, plum and in the sub-tropical fruits such as custard apple, grape, fig, ber, pomegranate and phalsa to bring a balance between vegetative and reproductive functions of the plant (Singh and Bal, 2008). The major purpose of pruning is to control canopy size and improves fruit quality. Custard apple (Annona squamosa L.) a member of annonaceae family is a tropical and subtropical fruit tree which is widely distributed in Asia, Africa and The America. Among annonaceous fruit custard apple is most commercial in India. Custard apple is useful for medicinal purpose, also used in Ayurvedic and Yunani system of medicine (Kowlska and Putt, 1990). Seed contains $30 \%$ oil, seed cake contains nitrogen to the tune of $4 \%$ is valued as manure. Flesh of the fruit is used for preparation of milk shakes and ice cream (Naidu and Saetor, 1954). Custard apple has many health and nutritional benefits. Rich source of dietary fiber which helps in indigestion (Navaneetrhakrishnan and Nattar, 2011). It increase in length and diameter of subsequent new shoots produced after pruning is directly proportional to the severity of pruning. Average fruit size and weight are also increased in pruned trees as compared to those in un-pruned once. The study was undertaken to provide exact and correct removal of plant parts in terms of length (distance) instead of percentage.

\section{Materials and Methods}

The present investigation was carried out at Custard apple research station, Ambajogai, district Beed, Maharashtra, India during 2016-17. The experimental material consist of 8 years old uniform plants of custard apple cv. Dharur-6. The trees were mentioned under uniform cultural practices during the entire course of investigation. The pruning was done $1^{\text {st }}$ week of April 2016 and treatment consist of 6 pruning levels, i.e. pruning at $5 \mathrm{~cm}$, pruning at $10 \mathrm{~cm}$, pruning at $15 \mathrm{~cm}$, pruning at $20 \mathrm{~cm}$, pruning at $25 \mathrm{~cm}$ and no pruning (control). And observations on growth and quality were recorded at monthly interval in randomly selected uniform healthy plants which were labeled. The different time and level of pruning were used are given below. The observation like period required for number of shoots per branch, days required for flowering and plant spread were recorded on randomly selected plant. The other observations like, number of fruit plant ${ }^{-1}$, average weight of fruit, weight of pulp, weight of peel, percent of pulp, number of seed fruit ${ }^{-1}$. 
The T.S.S. measured by using Erma hand refractrometer, titrable acidity by titration, reducing sugar, non-reducing sugar, total sugar (percent reducing sugar+percent nonreducing sugar) were recorded from randomly selected fruit. The statistical analysis done as per procedure given by Panse and Sukhatme (1967).

\section{Results and Discussion}

\subsection{Average weight of fruit, pulp and peel $(g)$}

From Table 1 the data showed that, the treatment $\mathrm{T}_{4}$ (pruning at $20 \mathrm{~cm}$ ) recorded significantly higher average fruit weight (263 g). As compared to control and it remained at par with treatment $\mathrm{T}_{3}$ (pruning at $15 \mathrm{~cm}$ ) is $251 \mathrm{~g}$. While minimum average fruit weight $(231 \mathrm{~g})$ was recorded in the treatment $\left(\mathrm{T}_{6}\right)$ control. Significantly maximum weight of pulp (111.74 g) was recorded in treatment $\mathrm{T}_{4}$ (pruning at $20 \mathrm{~cm}$ ) and it remained at par with the treatment $\mathrm{T}_{3}$ (pruning at $15 \mathrm{~cm}$ ) is $90.93 \mathrm{~g}$. While, the treatment $\left(\mathrm{T}_{6}\right)$ control gave minimum weight of pulp $(90.93 \mathrm{~g})$. Result pertaining to the effect of various treatments on average weight of peel was significantly affected due to various treatments. It is evident from data that treatment $\mathrm{T}_{4}$ (pruning at $20 \mathrm{~cm}$ ) recorded significantly maximum weight of peel (130.21 g) as compared to other treatment and it remained at par with treatment $\mathrm{T}_{3}$ (pruning at $15 \mathrm{~cm}$ ) 120.85 g. While, treatment $\left(T_{6}\right)$ control gave minimum weight of peel
(112.56 g). This might be due to the pruning may increases absorption of water, mobilization of minerals in pruned area. These findings are in accordance with the results obtained by Bruno and Evelyn (2001) in custard apple, Adhikari and Kandel (2015) in guava, Singh and Bal (2008) in ber tree.

\subsection{No. and weight of seeds fruit $^{-1}$}

Data regarding the number of seeds as influenced by pruning levels are presented in Table 1. It was observed that the effect of different pruning levels on number of seeds were nonsignificant. However, it was minimum (30) in the treatment $\mathrm{T}_{4}$ (pruning at $20 \mathrm{~cm}$ ). While it was highest (37) in treatment $\mathrm{T}_{6}$ (no pruning). Regarding weight of seed fruit ${ }^{-1}(\mathrm{~g})$, it is evident from data that treatment $\mathrm{T}_{6}$ (no pruning) recorded maximum weight of seed (27.51 g) as compared to other treatment. However it remained at par with treatment $T_{1}$ (pruning at 5 $\mathrm{cm}) 27.06 \mathrm{~g}_{1} \mathrm{~T}_{3}$ (pruning at $15 \mathrm{~cm}$ ) $26.64 \mathrm{~g}, \mathrm{~T}_{5}$ (pruning at $25 \mathrm{~cm}$ ) $24.36 \mathrm{~g}$ and $T_{2}$ (pruning at $10 \mathrm{~cm}$ ) $23.84 \mathrm{~g}$. minimum weight of seed was recorded in treatment $\mathrm{T}_{4}$ (pruning at $20 \mathrm{~cm}$ ). These findings are in accordance with the results obtained by Bruno and Evelyn (2001) in custard apple and Adhikari and Kandel (2015) in guava.

\subsection{Physical quality parameter}

3.3.1. Total soluble solid and acidity (\%)

From data (Table 1) Maximum total soluble solid $(23.80 \%)$

\begin{tabular}{llllllllllllllll}
\hline \multicolumn{2}{l}{ Table 1: Effect of different levels of pruning on quality attributes of custard apple (Annona squmosa L.) } \\
\hline Treatments & $\begin{array}{l}\text { Treatment } \\
\text { details }\end{array}$ & WF & WP & $\begin{array}{c}\text { Weight of } \\
\text { peel }(\mathrm{g})\end{array}$ & $\begin{array}{c}\text { Pulp } \\
\%\end{array}$ & $\begin{array}{c}\text { Peel } \\
\%\end{array}$ & NSF & WSF & $\begin{array}{c}\text { TSS } \\
(\%)\end{array}$ & $\begin{array}{c}\text { Acidity } \\
(\%)\end{array}$ & RS & NRS & TS \\
\hline $\mathrm{T}_{1}$ & $5 \mathrm{~cm}$ & 237 & 93.71 & 116.23 & 39.54 & 49.04 & 36 & 27.06 & 20.60 & 0.26 & 15.20 & 1.53 & 16.73 \\
$\mathrm{~T}_{2}$ & $10 \mathrm{~cm}$ & 243 & 99.31 & 119.76 & 40.87 & 49.28 & 31 & 23.84 & 22.50 & 0.25 & 16.98 & 1.74 & 18.72 \\
$\mathrm{~T}_{3}$ & $15 \mathrm{~cm}$ & 251 & 103.51 & 120.85 & 41.24 & 48.15 & 34 & 26.64 & 23.20 & 0.24 & 18.50 & 1.88 & 20.38 \\
$\mathrm{~T}_{4}$ & $20 \mathrm{~cm}$ & 263 & 110.72 & 131.23 & 42.10 & 49.90 & 30 & 21.05 & 23.80 & 0.24 & 16.65 & 1.69 & 18.34 \\
$\mathrm{~T}_{5}$ & $25 \mathrm{~cm}$ & 239 & 96.07 & 118.54 & 40.20 & 49.60 & 33 & 24.36 & 21.90 & 0.25 & 16.20 & 1.59 & 17.79 \\
$\mathrm{~T}_{6}$ & Control & 231 & 91.24 & 112.65 & 39.50 & 48.77 & 37 & 27.40 & 20.10 & 0.27 & 15.00 & 1.40 & 16.40 \\
$\mathrm{SEm} \pm$ & - & 6.25 & 3.80 & 3.37 & 1.24 & 1.64 & 1.64 & 1.30 & 0.82 & 0.01 & 0.65 & 0.08 & 0.70 \\
$\mathrm{CD}(p=0.05)$ & - & 18.86 & 11.47 & 10.16 & NS & NS & NS & 3.94 & 2.49 & NS & 1.96 & 0.26 & 2.11 \\
\hline
\end{tabular}

WF: Weight of fruit (g); WP: Weight of pulp (g); NSF: No.of seeds fruit ${ }^{-1}$; WSF: Weight of seeds fruit ${ }^{-1}$ (g); RS: Reducing sugars (\%); NRS: Non reducing sugars (\%); TS: Total sugars (\%)

was recorded in the treatment $\mathrm{T}_{4}$ (pruning at $20 \mathrm{~cm}$ ) and it remained at par with the treatment $\mathrm{T}_{3}$ (pruning at $15 \mathrm{~cm}$ ) $23.20 \%, \mathrm{~T}_{2}$ (pruning at $10 \mathrm{~cm}$ ) $22.50 \%$ and $\mathrm{T}_{5}$ (pruning at $25 \mathrm{~cm}$ ) $21.90 \%$. The minimum total soluble solid $20.10 \%$ was recorded in the treatment $\left(\mathrm{T}_{6}\right)$ control. These results are supported by Singh et al. (2001) in guava, Sheikh and Rao (2002) in pomegranate, Lakpathi et al. (2013) in guava. The effect of pruning levels on acidity per cent was found non-significant. However, it was maximum $0.27 \%$ in the treatment $\left(\mathrm{T}_{6}\right)$ control. While, it is minimum in $\mathrm{T}_{4}$ (pruning at $20 \mathrm{~cm}$ ) $0.24 \%$. The data revealed that acidity of fruit was not significantly influenced due to different levels of pruning. However it was recorded highest in treatment $\mathrm{T}_{6}$ (no pruning) $0.27 \%$, This may be due to Pruning improve physiology of leaves, thereby causing better translocation of vital components in fruit and assimilation of photosynthesis by developing fruit. Similarly it may increase activity of enzymes such as amylose which hydrolyze complex polysaccharides into simple sugars which accelerates the translocation of metabolites towards developing fruits. The results are in accordance with the findings reported by Mahajan and Dhillon (2002) in peach.

\subsubsection{Percent reducing sugar, non-reducing sugar and total sugar}

From the data (Table 1) that significantly maximum reducing 
sugar (18.50\%) was recorded in treatment $\mathrm{T}_{3}$ (pruning at 15 $\mathrm{cm}$ ). Which is at par with $\mathrm{T}_{4}$ (pruning at $20 \mathrm{~cm}$ ) $19.98 \%$. While, minimum reducing sugar (15.00\%) was recorded in treatment $\mathrm{T}_{6}$ (control). Also maximum non reducing sugar $1.88 \%$ was observed in treatment $\mathrm{T}_{3}$ (pruning at $15 \mathrm{~cm}$ ) and it remained at par with $\mathrm{T}_{2}$ (pruning at $10 \mathrm{~cm}$ ) $1.74 \%$ and $\mathrm{T}_{4}$ (pruning at 20 cm) $1.69 \%$. The minimum non-reducing sugar content $1.40 \%$ recorded in treatment $\left(\mathrm{T}_{6}\right)$ control. And maximum total sugar $20.38 \%$ was recorded in the treatment $\mathrm{T}_{3}$ (pruning at $15 \mathrm{~cm}$ ) and it remained at par with $\mathrm{T}_{2}$ (pruning at $10 \mathrm{~cm}$ ) $18.72 \%$ and $\mathrm{T}_{4}$ (pruning at $20 \mathrm{~cm}$ ) $18.34 \%$. While, minimum total sugars $16.40 \%$ was observed in treatment $\left(\mathrm{T}_{6}\right)$ control. These results are supported by Sheikh and Rao(2002) in pomegranate, Lakpathi et al. (2013) in guava and Kumar et al. (2014) in ber.

\section{Conclusion}

Light pruning at $20 \mathrm{~cm}$ level on plant shoots after harvesting of previous crop is beneficial for improving higher quality of Custard apple 'Cv. Dharur-6' these finding are based on one season data.

\section{References}

Adhikari, S., Kandel, T.P., 2015. Effect of time and level of pruning on vegetative growth, flowering, yield an quality of guava. International Journal of Fruit Science 15(3), 290-301.

Bruno, R.M., Evelyn, D.V., 2001. Effect of summer pruning and bark girdling on Cherimoya var. Conch lisa agriculture technical, 61(3).

Kowlska, M.T., Putt, D., 1990. Potential biomedical application for tropical fruit product, tropical garden fruit world. 1(4), 126-127.
Kumar, H., Katiyar, P.N., Singh, K.A., Rajkumar, B.V., 2014. Effect of different pruning severity on growth and yield of Ber (Zizyphus mauritiana Lamk) cv. Banarsi Karaka. International Journal of Current Microbiology 3(5), 935-940.

Lakpathi, G., Rajkumar, M., Chandrasekhar, R., 2013. Effect of pruning intensities and fruit load on growth, yield and quality of guava (Psidium guajava L.) cv. Allahabad Safeda under high density planting. International journal of Current research 5(12), 4083-4090.

Mahajan, B.V.C., Dhillon, B.S., 2002. Effect of pruning intensities on the fruit size, yield and quality of peach cv. Shan-i-Punjab Agricultural Science Digest 22(4), 281-282.

Naidu and Saetor, 1954. Fruit culture in India, I.C.A.R. New Delhi, 225-259.

Navaneethakeishnan, K., Nattar, S., 2011. Custard apple. Bibliography, Kisan world publication 32, 15-19.

Panse, V.G., Sukhatme, P.V., 1985. Statistical methods for Agricultural Workers, Indian Council of Agriculture Research, New Delhi.

Sheikh, M.K., Rao, M.M., 2002. Effect of pruning on fruit load on yield and quality in Pomogranate (Punica granatum L.) Var. Ganesh. Karnataka Journal of Agricultural Sciences 15(3), 549-555.

Singh, G., Singh, A.K., Rajan, S., 2001. Influence of pruning date on fruit yield of guava (Psidium guajava L.) under subtropics. Journal of Applied Horticulture 3(1), 37-40.

Singh, R., Bal, J.S., 2008. Pruning in ber (Ziziphus mauritiana LAMK). Agricultural Reviews 29(1), 61-67. 